\title{
The Concurrence of Sickle Cell Anemia with Diabetes Mellitus Type I and Complications (Nephropathy and Priapism)
}

\author{
Samih MAT ALQASSEM ${ }^{1 *}$, Abdulla M Al-matary², and Ali Ahmed Al-Zaazaai ${ }^{3}$ \\ ${ }^{1} \mathrm{MD}$ consultant of Aden Diabetes Centre, Yemen \\ ${ }^{2}$ Associated professor of medicine Aden University, Head of Aden Diabetes friends association and director of Aden diabetes center, Yemen \\ ${ }^{3}$ M.Sc Clinical pharmacy of China and products specialist with Al-Jabal Groups of Company in Yemen, Yemen
}

*Corresponding author: Samih MAT ALQASSEM, MD consultant of Aden Diabetes Centre, Yemen, Tel: 00967-717205458; E-mail: samihalqassim@ gmail.com

Received: 05 Nov, 2020 | Accepted: 25 Nov, 2020 | Published: 02 Dec, 2020

Citation: ALQASSEM SM, Al-matary AM, Al-Zaazaai AA (2020) The Concurrence of Sickle Cell Anemia with Diabetes Mellitus Type I and Complications (Nephropathy and Priapism). Int J Endocrinol Metab Disord 6(2): dx.doi.org/10.16966/2380-548X.170

Copyright: (C) 2020 ALQASSEM SM, et al. This is an open-access article distributed under the terms of the Creative Commons Attribution License, which permits unrestricted use, distribution, and reproduction in any medium, provided the original author and source are credited.

\section{Introduction}

The occurrence of diabetes mellitus is very low amongst patients with sickle cell disease. A numeral of studies failed to discover a single case of diabetes between patients with sickle cell anemia [1,2]. On the other hand, insufficient case reports of combined presentation of both the diseases without any problem have been reported between the black populations [35]. This case report defines a patient of sickle cell anemia with Type 1 diabetes mellitus complex with nephropathy and Priapism (painful erection of the penis).

\section{Case Presentation}

ASEEL 13-year-old male children came to ADEN DIABETES CENTRE (ADENYEMEN) with a history of diabetes mellitus type I since 9 years on basalbolus insulin (aspart insulin pre meals and glargine insulin at bedtime) and homozygous sickle cell anemia diagnosed at four years of his age complaining of lower limb edema and painful erection of penis (priapism). On examination: patient conscious, oriented to time, person, space. Pallor, not icterus. Weight: $37 \mathrm{~kg}$, high: $128 \mathrm{~cm}$ BMI: 22.6 in 88 percentile which indicates overweight. Chest: Normal vesicular breathing. CVS: S1 S2 S3 With functional systolic murmur At apex without radiation. Abdomen: No organomegaly.

Lab examination: Leucocytes count: $10000 \mathrm{cmm}, \mathrm{N}: 23.4 \% \mathrm{~L}$ : 69.2\%, M: 6.4E: 10.3\% , B :0.7\%, HGB: 7.2 g/d, PLT: 635 cmm, FBS: $98 \mathrm{mg} / \mathrm{dl}$, FBS: $181 \mathrm{mg} / \mathrm{dl}$, glycosylated-haemoglobin: $61 \%$, spot urin Albumin/creatinine Ratio: $692 \mathrm{mg} / \mathrm{g}$.Hb electrophorsis: HBS: 96\%, HB A2: 3.3\%, HB F: 0.7\%, Blood urea: $24 \mathrm{mg} / \mathrm{dl}$, serum creatinine: 0.9 mgldl.

\section{Discussion}

Coexisting sickle cell anemia with diabetes mellitus is very rare and nephropathy \& priapism (painful erection of the penis) static rarer. In this case, the history of DM type I since 9 years old with of investigations of blood sugar and Hb1c, and presence of elevations of Hemoglobin S 96\% and macro albumin urea (spot urine for albumin/ creatinine Ratio $692 \mathrm{mg} / \mathrm{g}$ ) confirmed the diagnosis of DM type I with homozygous sickle cell Anemia and its complication (priapism) with the presence of nephropathy (Macro albuminurea). The rarity of the concurrence of SCA and diabetes mellitus is reflected in the paucity of Nigerian studies on the subject, despite the high prevalence of the SCA gene among the populace. In India, in 2005, Mohapatra reported the first case of concurrent SCA and DKA [6]. A review of the literature revealed a lack of published population-based studies that determined the comparative prevalence of diabetes between patients with SCA in the tropics. However, it appears that the SCA population enjoys relation defense from diabetes. Determined the relation prevalence of diabetes between patients with SCA in the tropics. Theoretical mechanisms that have been suggested to explain this observation include low Body Mass Index (BMI), hyper metabolism, and genetic factors [7]. It is well established that SCA is related to a reliable pattern of anthropomorphic findings regarded as by low lean body mass and fat mass [8].

Considering that a high BMI is a known risk factor for the development of type 2 diabetes [9], individuals with a low BMI and fat mass should enjoy a relative 'protection' from T2DM. The effect of chronic disease, anemia, greater than before cardiac workload, hyperactive erythropoiesis, amplified protein turnover, inflammatory, and oxidative stress all donate to the hyper metabolic state in SCA $[10,11]$. On the other hand, it has been postulated that the paucity of reports of cases of concurrent SCA with DM may suggest that widely held of patients with SCA expired early, so, the relatively small numeral of patients lived for the clinical appearance of diabetes [5]. Though, this view is challenged by the knowledge that, in India and Saudi Arabia where SCA with the Asian haplotype which is less severe and associated with longer survival than the African haplotype, the 
co-existence of the two conditions is still rare. A significant proportion of patients with Asian haplotype survive beyond 30 years of age [12]. In spite of the extended survival, parallel SCA with DM has been rarely reported from India [13,14], suggesting that other unknown factors might be responsible for the rare association of the two clinical conditions. Morrison JC, et al. [14] postulated that genetic factors may play a role in this rare combination. They supported the hypothesis with the detail that both the $\beta$-globulin and the insulin genes are sited in the short arm of chromosome $11[15,8]$. Conversely, it is not known with certainty whether the genetic loci of insulin and $\beta$-globulin have an inhibitory effect on inheritance form or penetrance of the other. This is a subject for future investigation. Sheehan AG, et al. [16] reported the occurrence of pancreatitis in a three-year-old black girl with SCA following a vaso-occlusive crisis. This phenomenon could lead to damage to the pancreas with subsequent fibrosis and ultimately, a decrease in insulin production, leading to the development of DM. Iron excess due to numerous blood transfusions can result in islet $\beta$-cell impairment and reduced insulin production [17]. However, the absence of a history of previous multiple blood transfusions in our patient excluded such a possibility. In a new future study including 300 adults aged 20-70 year, 75 the prevalence of adults aged 20-70 years, 75 . The prevalence of albuminuria was $68 \%$ (26\% proteinuria) in homozygous persons as opposed to $32 \%$ (10\% proteinuria) in heterozygous patients [18] in this latter study, $21 \%$ of the patient's adrenal failure [19]. However, amplified tubular excretion of creatinine is preserved with the abnormal GFR Albuminuria is a very sensitive marker for the glomerular destruction affected in the SCD, for the glomerular destruction make happen in the SCD, unlike in other nephropathies such as type 2 diabetes. For this aim, some authors [20] have chosen measuring blood levels of cystatin Ctoserum creatinine for the estimate of GFR, though more studies are needed to approve this recommendation. In February1998, hydroxyurea established a novel indication, for the treatment of sickle cell disease [21].

It is agreed foruse in decreasing the incidence of pain fulcrises and then the need for blood transfusions in adult patients with repeated moderate to severe [22] painful crises (in general at minimum three during the previous 12 months). Management with $\mathrm{Hu}$ has been shown to stop the progress of proteinuria in children and even decrease therate of albuminuria [23]. This drug recovers anemia anderythrocyte rheology decreases leukocytosis and moderates the appearance of adhesion molecules. The joint use of ACE inhibitors and hydroxyurea can stop the development of microalbuminuria to proteinuria, [24] although its effect in avoiding renal failure has not been assessed.

\section{Conclusion}

In this challengeable case in which the occurrences of this complications nephropathy and priapism we cannot exactly Determined which disease (DM type I or SCA) correspond to it and the type of treatment that could relieve this complications In this condition, Is tarted ACI drugs (Captopril 6, $25 \mathrm{mg}$ TDS with Hydroxyurea HU $500 \mathrm{mg}$ BD) for both nephropathy and priapism (pain fulerection of the penis). Follow-up of the patient within weeks revealed improvement Painful erection of the penis with an improvement of proteinuria (spot urine for albumin /creatine ratio $21.6 \mathrm{mg} / \mathrm{g}$ ) With Decreased his weight to $34 \mathrm{~kg}$.

\section{Recommendations}

Continue hydroxyurea $\mathrm{HU}$ and $\mathrm{ACI}$ with follow up patient with complete Blood Count and spot urine for albumin/creatinine Ratio and blood for urea and creatinine. The basal-bolus regime of insulin continuation with a good assessment of blood glucose level in this patient. The National Glycohemoglobin Standardization Program (NGSP) provides data of different assays for diabetic monitoring in patients with inherited hemoglobin variants in which an exact A1C result cannot be obtained. Other procedures of average blood glucose concentrations can be monitored using the fructosamine test, also called glycated serum protein or glycated albumin. Limits however exist. Even though serum protein tests can be used to estimate circulating blood glucose over a period of time, it is still for a much shorter period, usually over the previous 2 to 3 weeks [25]. In all but one study, fructosamine confirmed a moderate to strong correlation with $\mathrm{A} 1 \mathrm{C}$ results and was recommended for use in cases of patients with hemoglobinopathy [26].

\section{Consent}

AEDEN DIABETES CENTER declares that written informed consent was obtained from the patient for publication of this case report.

\section{Ethical Approval}

Not applicable.

\section{Conflicts of Interest}

There are no conflicts of interest.

\section{References}

1. Morrison JC, Schneider JM, Kraaus AP, Kitabchi AE (1979) The prevalence of diabetes mellitus in sickle cell haemoglobinopathies. J Clin Endoc Met 48: 192195.

2. Reid HL, Photiades DP, Oli JM, Kaine W (1988) Concurrent sickle cell disease and diabetes mellitus. Trop Geogr Med 40: 201204.

3. Miodovnik M, Hurd WW, Lobel JS, Siddiqi TA (1987) Pregnancy associated with both insulin-dependent diabetes mellitusand sickle cell disease. A report of two cases. J Reprod Med 32: 317319.

4. Reid HL, Ene MD, Photiades DP, Famodu AA (1990) Insulindependent diabetes mellitus in homozygous sickle-cellanaemia. Trop Geogr Med 42: 172173.

5. Adekile AD, Jegenda AO (1990) Juvenile-onset diabetes mellitus in a sickle cell anaemia patient. East Afr Med J 67: 591593.

6. Mohapatra MK (2005) Type 1 diabetes mellitus in homozygous sickle cell anaemia. J Assoc Physicians India 53: 895-896.

7. Anonymous. Therapy insight: Metabolic and endocrine disorders in sickle cell disease: Metabolic and endocrine disorders in sickle cell disease: Endocrine disorders in patients with sickle cell disease.

8. Barden EM, Rawchak DA, Ohene-Frempong K, Stallings VA, Zemel BS (2002) Body composition in children with sickle cell disease. Am J Clin Nutr 76: 218-225.

9. Miller J, Silverstein JH, Rosen AL (2007) Type 2 diabetes in the child and adolescent. In: Lifshitz Fed (eds) Pediatric Endocrinology. $5^{\text {th }}$ Edition, New York, Informa Healthcare Inc.1: 169-182.

10. Akohoue SA, Shankar S, Milne GL, Morrow J, Chen KY, et al. (2007) Energy expenditure, inflammation, and oxidative stress in steady state adolescents with sickle cell anemia. Pediatr Res 61: 233-238.

11. Singhai A, Davies P, Wierenga KJ, Thomas P, Serjeant C (1997) Is there energy deficiencyin homozygous sickle cell disease? Am J Clin Nutr 66: 386-390. 
12. Kar BC (1991) Sickle cell disease in India. J Assoc Physicians India 39: 954-960.

13. Kar BC (2002) Clinical profile of sickle cell trait. J Assoc Physicians India 50: 1368-1371.

14. Morrison JC, Schneider JM, Kraaus AP, Kitabchi AE (1979) The prevalence of diabetes mellitus in sickle cell hemoglobinopathies. Clin Endocrinol Metab 48: 192-195.

15. Saad ST, Braga GS, Saad MJ (1989) Decreased C-peptide secretion in sickle cell anemia. Acta Haematol 82: 81-84.

16. Sheehan AG, Machida H, Butzner JD (1993) Acute pancreatitis in a child with sickle cell anaemia. J Natl Med Assoc 85: 70-72.

17. Swaminathan S, Alam MG, Fonseca VA, Shah SV (2007) The role of iron in diabetes and its complications. Diabetes Care 30: 1926-1933.

18. National Kidney Foundation (2002) K/DOQI clinical practice guidelines for chronickidney disease: Evaluation, classification, and stratification. Am J Kidney Dis 39: S1S266.

19. Guasch A, Cua M, Mitch WE (1996) Extent and the course of glomerular injury in patients with sickle cell anemia. Kidney Int 49: 786791.
20. Allon M, Lawson L, Eckman JR, Delaney V,Bourke E (1988) Effects of nonsteroidal antiinflammatory drugs on renal function in sickle cellanemia. Kidney Int 34: 500506.

21. Food and Drug Adminidstation. Med watch.

22. Dover GJ, Charache S (1992) Hydroxyurea inductionof fetal hemoglobin synthesis in sicklecell disease. Semin Oncol 19: 6166.

23. Hatch FE, Crowe LR, Miles DE, Young JP, Portner ME (1989) Altered vascular reactivity in sickle hemoglobinopathy. A possible protective factor from hypertension. Am J Hypertensive 2: 2-8.

24. Fitzhugh CD, Wigfall DR, Ware RE (2005) Enalapril and hydroxyurea therapy for children with sickle nephropathy. Pediatr Blood Cancer 45: 982985.

25. Sickle Cell Trait and Other Hemoglobinopathies and Diabetes (For Providers) (2011) National Diabetes Information Clearinghouse (NDIC).

26. Arlene S (2008) Glycemic Control and Hemoglobinopathy: When A1C May Not Be Reliable. Diabetes Spectrum 21: 4649. 